Cartensen, H., Terner, N., Thoren, L., and Wide, L. (1972). Acta Chirurgica Scandinavica, 138, 1 .

Eik-Nes, K. B. (1964). Canadian fournal of Physiology and Pharmacology, $42,671$.

Eik-Nes, K. B. (1969a). American fournal of Physiology, 217, 1764.

Eik-Nes, K. B. (1969b). General and Comparative Endocrinology, Suppl. No. 2, p. 87.

Faiman, C., and Winter, J. S. D. (1971). fournal of Clinical Endocrinology and Metabolism, 33, 186.

Forrest, M. G., Rivarola, M. A., and Migeon, C. J. (1968). Steroids, 12, 323. Gillespie, C. A., and Edgerton, V. R. (1970). Hormone and Metabolic Research, 2, 364.

Hales, C. M., and Randle, P. J. (1963). Biochemical fournal, 88, 137.

Hoffman, W. S. (1937). Fournal of Biological Chemistry, 120, 51

Horton, R., Kato, T., and Sherins, R. (1967). Steroids, 10, 245.

Horton, R., and Tait, J. F. (1966). Fournal of Clinical Investigation, 45,

Keul, J., Doll, E., and Keppler, D. (1967). Experentia, 23, 974.
Murphy, B. E. P. (1967). Fournal of Endocrinology and Metabolism, 27, 973. Paul, P., and Issekutz, B. (1967). Fournal of Applied Physiology, 22, 615.

Paulsen, C. A. (1968). In Textbook of Endocrinology, ed. R. H. Williams,

4th edn., ch. 6, p. 414. Philadelphia, Saunders. $12,577$.

Sutton, J. R., Coleman, M. J., Millar, A. P., Lazarus, L., and Russo, P. (1972). Medical fournal of Australia, 2, 127.

Sutton, J. R., Young, J. D., Lazarus, L., Hickie, J. B., and Maksvytis, J. (1968). Lancet, 2, 1304.

Sutton, J. R., Young, J. D., Lazarus, L., Hickie, J. B., and Maksvytis, J. (1969). Australasian Annals of Medicine, 18, 84.

Vendsalu, A. (1960). Acta Physiologica Scandinavica, 49, Suppl. No. 173,

Wahren, J., Felig, P., Ahlborg, G., and Jorfeldt, L. (1971). Fournal of Clinical Investigation, 50, 2715.

Yen, S. S. C., Tsai, C. C., Najtolin, F., Kandenberg, G., and Ajabor, L. (1972). Journal of Clinical Endocrinology and Metabolism, 34, 671.

\title{
Interaction between Clonidine and Desipramine in Man
}

\author{
ROBIN H. BRIANT, JOHN L. REID, COLIN T. DOLLERY
}

British Medical fournal, 1973, 1, 522-523

\section{Summary}

Interaction between the tricyclic antidepressant desipramine and the antihypertensive agent clonidine has been investigated in five hypertensive patients in a doubleblind placebo controlled study. Introduction of the tricyclic antidepressant led to loss of blood pressure control in four of the patients. The average blood pressure rise in the desipramine period compared with the placebo period was $22 / 15 \mathrm{~mm} \mathrm{Hg}$ in the lying position and $12 / 11$ $\mathrm{mm} \mathrm{Hg}$ standing. Thus addition of a tricyclic antidepressant may lead to loss of blood pressure control in a hypertensive patient treated with clonidine.

\section{Introduction}

The hypotensive action of both bethanidine and guanethidine is impaired by tricyclic antidepressant drugs (Leishman et al., 1963; Mitchell et al., 1967; Mitchell et al., 1970). Their antihypertensive effect is mediated by adrenergic neurone blockade and is dependent on uptake into and concentration in peripheral adrenergic neurones. This mechanism, $\mathrm{Uptake}_{1}$, is blocked by the tricyclic compounds (Iversen, 1971).

Conolly et al. (1969) reported that the hypotensive action of clonidine in one patient appeared to be impaired by the introduction of imipramine $75 \mathrm{mg} /$ day. Recently we (Briant and Reid, 1972) showed that the hypotensive action of clonidine in rabbits is reduced about twentyfold by pretreatment with another tricyclic antidepressant, desipramine.

The present study was carried out to determine whether this interaction occurs in man.

\section{Materials and Methods}

Five hypertensive patients on long-term medication with clonidine and a diuretic were asked to join the study. After the

\footnotetext{
M.R.C. Clinical Pharmacology Research Group, Royal Postgraduate Medical School, London W12 0HS

ROBIN H. BRIANT, M.B., M.R.A.C.P., Wellcome Research Fellow in Clinical Pharmacology

COLIN T. DOLLERY, M.B., F.R.C.P., Professor of Clinical Pharmacology

Department of Medicine, Hammersmith Hospital, London W12 0HS JOHN L. REID, B.M., M.R.C.P., Senior Registrar
}

TABLE I-Details of the Patients Studied

\begin{tabular}{|c|c|c|c|c|c|}
\hline $\begin{array}{l}\text { Case } \\
\text { No. }\end{array}$ & Sex & Age & $\begin{array}{c}\text { Clonidine Dose } \\
\text { ( } \mu \mathrm{g} / \text { Day })\end{array}$ & Diuretic & $\begin{array}{l}\text { Duration of } \\
\text { Therapy (Years) }\end{array}$ \\
\hline 1 & F. & 47 & 600 & $\begin{array}{l}\text { Chlorthalidone } \\
100 \mathrm{mg} \text { alternate days }\end{array}$ & 3 \\
\hline 2 & M. & 43 & 3,200 & Hydrochlorothiazide & 2 \\
\hline 3 & M. & 41 & 1,050 & $\begin{array}{c}\text { Hydrochlorothiazide } \\
50 \mathrm{mg} \text { daily }\end{array}$ & 3 \\
\hline 4 & M. & 63 & 1,500 & $\begin{array}{l}\text { Hydrochlorothiazide } \\
50 \mathrm{mg} \text { daily }\end{array}$ & 3 \\
\hline 5 & M. & 45 & 1,800 & $\begin{array}{l}\text { Chlorthalidone } \\
100 \mathrm{mg} \text { alternate days }\end{array}$ & 3 \\
\hline
\end{tabular}

investigation had been explained to them all freely consented. Details of the patients are given in table I.

In each patient the same daily dose of clonidine and diuretic was maintained throughout the study, which was divided into three parts. The first was a period of baseline observation to ensure that control was adequate and consistent. The blood pressure, lying and standing, was measured with a sphygmomanometer on at least three occasions over at least three weeks. Several recordings were made at each visit, and the visits were kept as nearly as possible to the same time, most being made at the patient's home after work. Periods 2 and 3 each comprised two weeks during which the patient took either desipramine $75 \mathrm{mg} /$ day or the same number of matched placebo tablets. The patients were allocated at random to start with either placebo or desipramine and the study was carried out under double-blind conditions. During periods 2 and 3 the patients were seen at least twice a week.

Only one patient (case 3) did not keep to the agreed protocol. His blood pressure rose considerably 24 hours after beginning with the active drug. This was associated with headache and profuse sweating. A reduction in the desipramine dose resulted in a lessening of symptoms, but the blood pressure remained high so the study was terminated.

Average blood pressure for each patient was calculated from the whole run-in period and from the second week of each treatment period except in case 3 , where the comparative periods were week 1 of each treatment. Within-patient observations were compared by the unpaired Student's $t$ test, and group observations by the paired $t$ test.

\section{Results}

Four of the five patients showed a significant $(P<0.01)$ rise in blood pressure in at least one position on desipramine, while 
TABLE II-Group Mean Blood Pressure Values (mm Hg) \pm S.E. for the Three Observation Periods. Pretreatment Ranges are shown for Comparison

\begin{tabular}{|c|c|c|c|c|c|c|}
\hline & & & $\begin{array}{c}\text { Pretreated } \\
\text { (Range) }\end{array}$ & Baseline & Placebo & Desipramine \\
\hline $\begin{array}{l}\text { Lying } \\
\text { Standing }\end{array}$ & $\left\{\begin{array}{l}\text { Systolic } \\
\text { Diastolic } \\
\text { Systolic } \\
\text { Diastolic }\end{array}\right.$ & $\begin{array}{l}\because \\
\because\end{array}$ & $\begin{array}{l}170-220 \\
110-140 \\
180-240 \\
120-135\end{array}$ & $\begin{array}{r}146.0 \pm 9.6 \\
88.4 \pm 2.8 \\
132.3 \pm 9.3 \\
87.7 \pm 2.4\end{array}$ & $\begin{array}{r}142.0+8.5 \\
86.4 \pm 4.5 \\
126.6 \pm 7.1 \\
84.5 \pm 4.0\end{array}$ & $\begin{array}{r}163.9 \pm 12.2 * \\
101.7 \pm 5.6 * \\
138.6 \pm 12.2+ \\
94.7 \pm 7.7 \dagger\end{array}$ \\
\hline
\end{tabular}

* Significantly greater than in placebo period $(P<0.01)$.

+ Significantly greater than in placebo period $(P<0.05)$.

the fifth showed a modest increase in his postural blood pressure fall. The group mean blood pressure rose in the desipramine period by an average of $21.9 / 15.3 \mathrm{~mm} \mathrm{Hg}$ lying $(P<0.01)$ and $12.0 / 11.5 \mathrm{~mm} \mathrm{Hg}$ standing $(P<0.05)$. The group mean blood pressures, lying and standing, are shown in table II for the three observation periods. The range of pretreatment values are included for comparison. The difference between the group mean blood pressure in baseline and placebo periods was not significant.

The response of two patients to the introduction of desipramine is shown in figs. 1 and 2. The blood pressure rise in the second week of treatment shown in case 1 (fig. 1) was the response most frequently observed. The early and more dramatic rise of blood pressure shown in case 3 (fig. 2) was similar to the hypertensive reactions induced by sudden clonidine withdrawal.

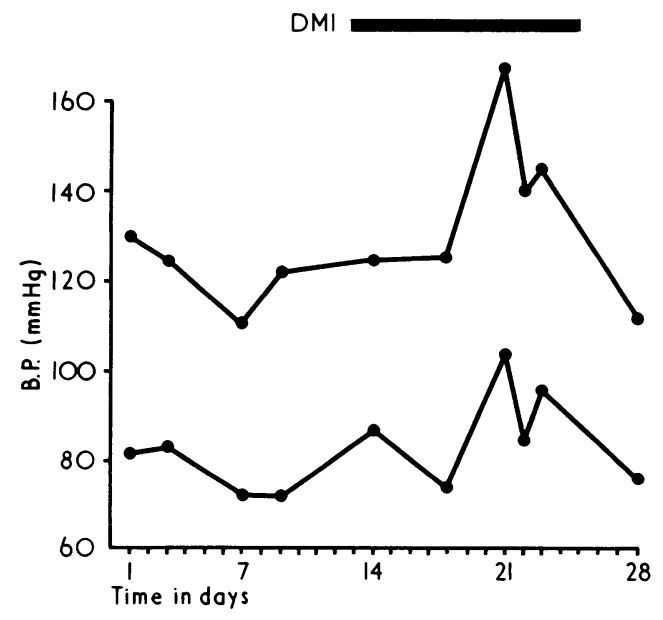

FIG. 1-Case 1. Lying blood pressure through placebo and desipramine (DMI) periods.

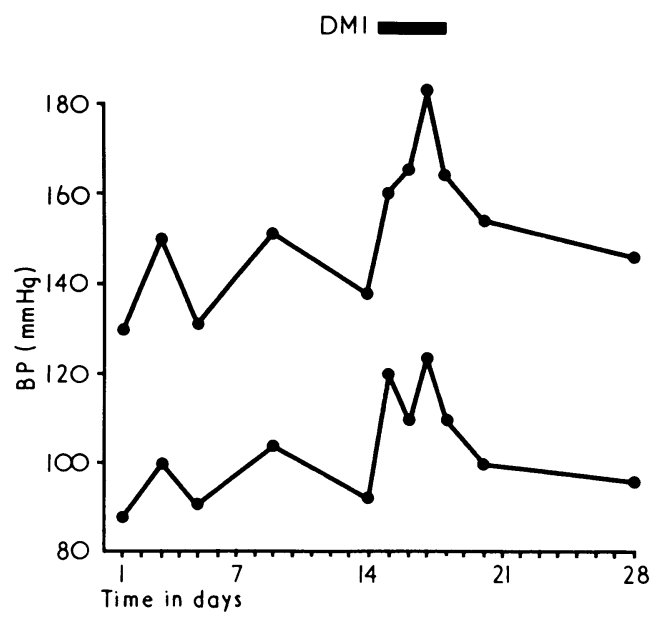

FIG. 2-Case 3. Standing blood pressure through placebo and desipramine (DMI) periods.

\section{Discussion}

The introduction of desipramine in a double-blind trial caused a rise in arterial pressure in four out of five hypertensive patients on treatment with clonidine. The effect was more prominent in the supine position than in the erect. The increase in blood pressure when desipramine is added to a clonidine regimen is of less rapid onset than that reported with the interaction between bethanidine and tricyclic antidepressants. $A$ rise in blood pressure within 24 hours of starting desipramine was seen in only one patient, and this was the only instance in which the blood pressure rose to the pretreatment level. In the three other patients the change, though less, resulted in unacceptable arterial pressure levels.

The mechanism of the hypotensive action of clonidine has not been fully established. There is evidence that it causes a reduction in central sympathetic outflow (Schmitt et al., 1968), but Zaimis and Hanington (1969) showed that a peripheral mechanism may be involved. Peripheral adrenergic neurone blockade has been demonstrated at relatively low concentrations of clonidine (Werner et al., 1972) although there is no evidence that this drug is concentrated in adrenergic neurones, as are bethanidine and guanethidine. Desipramine may impair the hypotensive action of clonidine by an action on neuronal uptake, but the tricyclic compounds have other pharmacological actions, such as alpha-adrenoreceptor blockade, which could be relevant.

The clinical implications of this finding are evident. Clonidine now joins the list of hypotensive drugs-bethanidine, guanethidine, and debrisoquine (Mitchell et al., 1970)-which cannot be used with impunity in conjunction with tricyclic antidepressant therapy. Only methyldopa has been shown by these workers to exert its full hypotensive effect in the presence of the tricyclic compounds.

Any patient whose blood pressure is controlled with clonidine and who requires therapy for concomitant depression should be carefully observed if tricyclic drugs are used.

We are grateful for the help of Miss D. Frances Milne in the documentation of these cases, and Miss Susan Banks for the preparation of the manuscript. Dr. G. Beaumont, of Ciba-Geigy, supplied desipramine and matched placebo tablets. The work was suppor'ed by the Wellcome Trust (R.H.B.) and the Medical Research Council (J.L.R.).

\section{References}

Briant, R. H., and Reid, J. L. (1972). British fournal of Pharmacology, 46,

Conolly, M. E., Paterson, J. W., and Dollery, C. T. (1969). In Catapres in Hypertension, ed. M. E. Conolly, p. 167. London, Butterworths. in Hypertension, ed. M. E. Conolly, p. 167. London, Butte
Iversen, L. L. (1971). British fournal of Pharmacology, 41, 571.

Iversen, L. L. (1971). British .7ournal of Pharmacology, 41, 571. 112.

Mitchell, J. R., Arias, L., and Oates, J. A. (1967). fournal of the American Medical Association, 202, 973

Mitchell, J. R., Cavanaugh, J. H., Arias, L., and Oates, J. A. (1970). fournal of Clinical Investigation, 49, 1596.

Schmitt, H., Schmitt, H., Boissier, J. R., Guidecelli, J. F. and Fichelle, J. (1968). European fournal of Pharmacology, 2, 340.

Werner, U., Starke, K., and Schumann, H. J. (1972). Archives of International Pharmacodynamics, 195, 282.

Zaimis, E., and Hanington, E. (1969). Lancet, 2, 298. 